\title{
Contents, Vol. 53, 1988
}

\section{No. 1 Original Paper}

Left Ventricular Diastolic Function during the First Month of Life

Fouron, J.-C; Heitz, F.; Carceller, A.-M.; Ducharme, G.; van Doesburg, N.H.;

Davignon, A 1

The Ontogeny of Serum Immunoreactive Pancreatic Lipase and Cationic Trypsinogen in the Premature Human Infant

Cleghorn, G.; Durie, P.; Benjamin, L.; Dati, F

Arginine Vasotocin and a Novel Oxytocin-Vasotocin-Like Material in Plasma of Human Newborns

Ervin, M.G.; Amico, J.A.; Leake, R.D.; Ross, M.G.; Robinson, A.G.; Fisher, D.A. . 17

Clearance of Treatment Doses of Surfactant. Effect of Lipid Extraction and Aggregate

Sizes

Pettenazzo, A.; Jobe, A.; Ikegami, M.; Seidner, S 23

Metabolism of Mono-(2-Ethylhexyl)phthalate in Fetal, Neonatal and Adult Rat Liver

Sjöberg, P.; Bondesson, U.; Gustafsson, J 32

Development of Luminal Protein Digestion in Suckling and Weanling Rats

Britton, J.R.; Koldovský, $0 \quad 39$

In vivo Effects of Glucocorticoid Excess on the Contents of the Rat Fetal Liver in Erythroid Progenitors

Billat, C; Mayeux, P.; Felix, J.-M.; Jacquot, R

Age-Related Changes in the Kinetics of Iron Absorption across the Guinea Pig Proximal Intestine in vivo

Srai, S.K.S.; Debnam, E.S.; Boss, M.; Epstein, $0 \quad 53$

Acknowledgement 60

No. 2 Original Paper

Effect of Distal Endotracheal Bias Flow on PaCÛ2 during High Frequency Oscillatory Ventilation

Bancalari, A.; Bancalari, E.; Hehre, D.; Suguihara, C; Gerhardt, T.; Goldberg, R.N. . 61 Aspartate Aminotransferase and Alanine Aminotransferase Serum Activities in Neonatal Transient Myocardial Ischemia

Zanardo, V.; Vispi, L.; Rizzo, L; Cittar, H.; Pellegrino, P.A 68

Measurement of Fetal Responses to Vibroacoustic Stimuli. Habituation in Fetal Sheep

Leader, L.R.; Stevens, A.D.; Lumbers, E.R 73

Induction of Neural Tube Defects and Skeletal Malformations in Mice following Brief

Hyperthermia in utero

Shiota, K 86

Ovine Fetal Urine Contribution to Amniotic and Allantoic Compartments

Ross, M.G.; Ervin, M.G.; Rappaport, V.J.; Youssef, A.; Leake, R.D.; Fisher, D.A. . 98 Effects of Maternal Hypocaloric Diet Feeding on Neonatal Rat Brown Adipose Tissue 
Felipe, A.; Villarroya, F.; Mampel, T 105

Effect of Prostaglandin E2 on Adenylate Cyclase Activity in Isolated Glomeruli and Tubules during Postnatal Maturation of Rat Renal Cortex

Judes, C; Helwig, J.-J.; Bollack, C 113

IV

Contents

No. 3 Original Paper

Circulating Catecholamines and Glucagon in Infants of Strictly Controlled Diabetic Mothers

Artal, R.; Doug, N.; Wu, P.; Sperling, M.A 121

Serum Lipoproteins in Venous Blood Serum from Birth to the End of the First Week:

Feeding Influences

Tenenbaum, D.; Gambert, P.; Meunier, S.; d'Athis, P.; Nivelon, J.L.; Lallemand, C. . 126

Physiologic Jaundice in the Nigerian Neonate

Okolo, A.A.; Omene, J.A.; Scott-Emuakpor, A.B 132

Decreased Serum Alpha-Amylase Levels in Infected Nigerian Newborn Infants

Okolo, A.A.; Okorodudu, A.; Glew, R.H.; Omene, J.A 138

Relationship between Maternal Parity, Basal Prolactin Levels and Neonatal Breast Milk Intake

Zuppa, A.A.; Tornesello, A.; Papacci, P.; Tortorolo, G.; Segni, G.; Lafuenti, G.; Moneta,

E.; Diodato, A.; Sorcini, M.; Carta, S 144

Differences between Pregnant and Nulliparous Rats in Basal and Stress Levels of Metallothionein

Hidalgo, J.; Giralt, M.; Garvey, J.S.; Armario, A 148

Neutrophil-Mediated Killing, Opsonization, and Serum-Mediated Killing of Escherichia coli Kl by Neonatal Rats

Lassiter, H.A.; Christensen, R.D.; Parker, C; Rothstein, G 156

Effect of Maternal Nicotine Exposure on Growth in vivo of Lung Tissue of Neonatal Rats

Maritz, G.S 163

Metabolic Development of Porcine Fetal Adipose Tissue. A Role for Central Regulation

Ramsay, T.G.; Hausman, G.J.; Martin, R.J 171

No. 4 Perinatal Nephrology

Foreword

Guignard, J.-P 185

Major Malformations of the Urinary Tract. Anatomic and Genetic Aspects

Gillerot, Y.; Koulischer, L 186

Use of Experimental Models to Study the Development of Renal Function

Fukuda, Y.; Larsson, S.; Celsi, G.; Lechene, C; Aperia, A 197

Hormonal Regulation of Renal Function during Development

Robillard, J.E.; Nakamura, K.T 201

Renal Response to Vasopressin in Premature Infants: What Is New?

Sulyok, E 212

Renal Aspects of Calcium and Phosphorus Metabolism in Preterm Infants

Senterre, J.; Salle, B 220

Renal Function and Fluid Therapy in High Risk Infants

$\mathrm{Oh}, \mathrm{W} 230$

Functional Renal Insufficiency: Role of Adenosine

Gouyon, J.-B.; Guignard, J.-P237 
Adverse Effects of Drugs on the Immature Kidney

Guignard, J.-P.; Gouyon, J.-B243

Aminoglycoside Nephrotoxicity and Urinary Excretion of N-Acetyl-Beta-D-Glucosaminidase

Langhendries, J.P.; Battisti, O.; Bertrand, J.M

253

Author Index 260

Subject Index 260

Contents

$\mathrm{V}$

No. 5 Original Paper

Effect of Total Parenteral Nutrition on Lipase Activity in the Stomach of Very Low Birth Weight Infants

Mehta, N.R.; Liao, T.H.; Hamosh, M.; Smith, Y.F.; Hamosh, P 261

Pepsin and Its Multiple Forms in Early Life

Adamson, I.; Esangbedo, A.; Okolo, A.A.; Omene, J.A 267

The Doppler Flow Velocity Waveform in the Fetal Internal Carotid Artery with Respect to Fetal Behavioural States. A Longitudinal Study

van den Wijngaard, J.A.G.W.; van Eyck, J.; Noordam, M.J.; Wladimiroff, J.W.; van

Strik, R 274

Effect of Nimodipine on Newborn Lamb Cerebral Blood Flow

Mogilner, M.; Ashwal, S.; Dale, P.S.; Longo, L.D 279

Influence of Radiant Heat Stress on Respiratory Water Loss in New-Born Lambs

Riesenfeld, T.; Hammarlund, K.; Jonzon, A.; Sedin, G 290

Prenatal Development of the Brattleboro Rat Is Influenced by Genotype and Lysine Vasopressin Treatment of the Mother

Snijdewint, F.G.M.; Boer, G.J.; Swaab, D.F 295

Early Development of the Thyroid Axis in the Brattleboro Rat

Huffman, L.; Hedge, G.A 305

Maternal-Fetal Relationship in Ammonia Metabolism during Late Gestation in the Rat

Garcia, M.V.; Martín-Barrientos, J.; Medina, J.M 315

No. 6 Original Paper

Vitamin D Metabolism in Preterm Infants: Effect of a Calcium Load

Delvin, E.E.; Salle, B.L.; Glorieux, F.H.; David, L.S321

Intestinal Absorption of Calcium in Newborn Piglets. Role of Vitamin D

Lachenmaier-Currle, U.; Harmeyer, J327

Characteristics of Postnatally Induced Alterations in Thyroxine-5'- and 5-Monodeiodinat-

ing Activities in Several Pig Tissues

álebodziński, A.B.; Brzeziñska-Slebodzińska, E 336

Changes in the cAMP Synthesis by Fetal Thyroid during the 5 Last Days of the Intrauterine

Life in the Rat

Pic, P.; Bouquin, J.-P.; El Atiq, F 346

Effect of Chronic Modification of Diet Fat and Cholesterol during Gestation on Plasma

Hormones and Hepatic Enzyme Activities in Rat Fetus

Innis, S.M.; Haave, N.C 355

Pyruvate Carboxylase, Phosphate-Dependent Glutaminase and Glutamate Dehydrogenase in the Developing Rat Small Intestinal Mucosa 
Hahn, P.; Taller, M.; Chan, H362

Development of Intestinal Carnitine Transport in Rats

Leichter, J.; Hahn, P 367

Author Index 371

Subject Index 373 